\title{
TOWARD A MORE COHERENT POLICY FOR FUNDING INDIAN EDUCATION
}

\author{
Daniel M. Rosenfelt*
}

In 1969 the Special Senate Subcommittee on Indian Education published the results of its extensive study, concluding that "our Nation's policies and programs for educating American Indians are a national tragedy." The Nixon administration, ${ }^{2}$ independent scholars, ${ }^{3}$ and public interest groups ${ }^{4}$ reached similar conclusions not only as to the deplorable state of Indian education, but also with respect to the most important new policy needed to bring improvement: increased Indian participation in and control of Indian education programs. ${ }^{5}$

In six short years, dramatic changes have taken place both in Washington and in Indian communities throughout the nation. The Indian Education Act of 1972 (IEA) ${ }^{6}$ established broad new programs of federal financial assistance to Indian children enrolled in public schools and created a new bureau within the United States Office of Education to administer the Act. ${ }^{7}$ In 1975 the Bureau of Indian Affairs drastically revised the regulations governing its Johnson-O'Malley program (JOM). ${ }^{8}$ Earlier in that year Congress passed a wide-ranging Indian Self-Determinátion ${ }^{9}$ and Education Assistance Act ${ }^{10}$ which

\footnotetext{
* Associate Professor of Law, Gonzaga University School of Law; formerly Senior Staff Attorney, Center for Law and Education, Harvard University; Staff Attorney, California Indian Legal Services, Native American Rights Fund Division.

1. Special Subcomm. on Indian Education, Comm. on labor and Public Welfare, Indian Education: A National Tragedy-A National. Challenge, S. Rep. No. 501, 91 st Cong., lst Sess. XIV (1969).

2. Message from the President of the United States, Recommendations for Indian Policy, H.R. Doc. No. 363, 91st Cong., 2d Sess. 6 (1970).

3. E.g., 5 R. Havighurst, The National Study of American Indian Education: The Education of INDIAN ChILDREN ANd YOUTH 27 (1970).

4. E.g., NAACP Legal Defense and Educ. Fund, An Even Chance 59-64 (1971) [hereinafter cited as An Even Chance].

5. See generally Rosenfelt, Indian Schools and Community Control, 25 Stan. L. Rev. 489 (1973).

6. 20 U.S.C. $\$ \$ 241$ aa, $887 \mathrm{c}, 1211$ a (Supp. III, 1974).

7. Id. $\$ 441$.

8. 40 Fed. Reg. 51303 (Nov. 4, 1975).

9. Pub. L. No. 93-638, 88 Stàt. 2203 (Jan. 4, 1975). Title I of the Indian Self-Determination and Education Assistance Act establishes no new major programs, but it directs the Secretary of Interior, upon the request of any Indian tribe, to enter into a contract with tribally sponsored organizations to conduct or administer all or a portion of any Indian program now conducted by the Department of Interior. Id. \$ 102(a). A similar provision applies to the Indian Health Service programs administered by the Department of Health, Education and Welfare. $I d . \S 103(a)$. Since education is the largest program administered by the Department of Interior's Bureau of Indian Affairs, the effect of this Act is to pave the way for eventual Indian control of the existing federal school system.

10. Title 11 of P.L. 638 is known as the Indian Education Assistance Act and consists of two
} 
modified programs administered by the Bureau of Indian Affairs and the United States Office of Education. Indian parents in communities throughout the nation now participate in education program formation to a greater degree than before, ${ }^{11}$ and some Indian organizations operate and administer their own programs. ${ }^{12}$

These recent innovations, however, have emerged less as the product of carefully planned reform than as a result of partisan politics, ${ }^{13}$ organizational $^{14}$ and personal ${ }^{15}$ rivalries, and differing philosphies and priorities at every decision-making level from the presidency, through Congress and the federal agencies, to the Indian tribes ${ }^{16}$ and communities. ${ }^{17}$ The inevitable re-

parts. Part A amends the Johnson-O'Malley Act, 25 U.S.C. $\$ \$ 452-55$ (1970), and is discussed in the text accompanying notes 149-61 infra. Part B authorizes a new program of school construction and is discussed in the text accompanying notes 64-66 infra.

11. See, e.g., Testimony of Morris Thompson, Comm'r of Indian Affairs, in Hearings on Dep't of the Interior and Related Agencies Appropriations for 1975 Before a Subcomm. of the House Comm. on Appropriations, 93d Cong., 2d Sess., pt. 1, at 158 (1974) [hereinafter cited as FY.1975 House Appropriations Hearings].

12. Cf. Testimony of Morris Thompson, Comm'r of Indian Affairs, in Hearings on Dep't of the Interior and Related Agencies Appropriations Fiscal Year 1975 Before the Senate Comm. on Appropriations, 93d Cong., 2d Sess., pt. 3, at 1315-18 (1974).

13. The Nixon Administration, for example, consistently opposed the Indian Education Act of 1972 whose most prominent sponsor was Senator Edward M. Kennedy. Cf. D. RATHER \& G. Gates, The Palace Guard 197-202 (1975). In fairness, that administration opposed other education programs on philosophical grounds.

14. The two federal agencies concerned with Indian Education, the Bureau of Indian Affairs and the United States Office of Education, have failed to coordinate their activities and have given each other only minimal cooperation despite continuous urging by Indian people and concerned congressmen.

15. In the United States Senate, for example, the Interior and Insular Affairs Committee, which has jurisdiction over the Department of Interior, is chaired by Senator Henry Jackson. The Committee on Education and Labor with responsibility for the Office of Education has Senators Kennedy and Mondale among its senior members. In framing Indian education legislation, a great deal of energy was expended by each committee staff in trying to outmaneuver the competing committee.

16. Indian tribal governments have generally opposed the extension of federal benefits to urban Indians. Their concern has been that a large increase in the number of eligible "Indian beneficiaries" of a program will result not in increased appropriations, but in reduced sums going to the reservations. A secondary source of antagonism towards urban Indians derives from the notion that many persons now claiming benefits as "Indians" turned their backs on the reservations when the going was tough. Many of these urban dwellers are said to have tried to deny their Indian heritage. Further, urban Indians are viewed by some tribal leaders as too militant and disrespectful of custom and tradition.

17. Within the larger Indian tribes, it is common to find differences on major issues between the elected tribal government and local community representatives. To some extent this is a result of the different constituencies represented. In some tribes, there is a burgeoning women's movement apparent in the local communities which views with some distaste the male dominated tribal council. Most often, however, tribal council members concerned with economic development and natural resources place lower priority on educational matters than do local community representatives.

The tribal-local conflict may surface when the question of parent participation or veto power in an education program is sought to be lodged in some Indian group. For example, section 202 of the Indian Self-Determination and Education Assistance Act adds a new section 5 to the Johnson-O'Malley Act providing for the establishment of a locally elected parent committee to 
sult is some duplication, some waste, and some inconsistency in federal programs for Indian education. A key factor in the formulation of a coherent approach to Indian education is the design of funding legislation. In addition to the direct impact of funding on the delivery of educational services, disputes concerning discrimination and jurisdiction often are exacerbated by confusion over funding.

In recognition of this condition, Congress required the Secretary of the Interior to submit a comprehensive analysis of the interrelationship between five major federal programs designed to assist Indian children in public schools. ${ }^{18}$ The Secretary's study, completed in October $1975,{ }^{19}$ should stimulate extended discussions among persons concerned with Indian education. In addition, the congressionally created American Indian Policy Review Commission will, as part of its final report, address itself to the problems of Indian education policy. ${ }^{20}$ This article is one attempt to examine selected Indian educational policy issues from the perspective of funding and to offer suggestions for making federal aid programs more effective.

About 80 per cent of the 350,000 American Indian school children attend public schools. ${ }^{21}$ At least half of these children attend schools funded in large measure by local property taxes. However, the remaining half attend schools in "reservation" districts containing blocks of Indian land held in trust by the United States and exempt from real property taxation. ${ }^{22}$ Accordingly, in reservation districts the federal government provides Impact Aid funds in lieu of local property taxes and special assistance for school construction.

"Supplemental" or "categorical" programs supply additional sums for the special educational needs of selected groups of students. Funded at almost two billion dollars, ${ }^{23}$ the largest of these national programs, Title I of the Elemen-

approve or disapprove the proposed JOM program. 88 Stat. 2213 (Jan. 4, 1975). At the same time, section 102(a) directs the Secretary of Interior to enter into a contract to administer the JOM program upon request of the tribe. 88 Stat. 2206 (Jan. 4, 1975). Approval for such a tribal request is not required from the locally elected parent committee. Already, for instance, the Portland area office has received a request to contract from the Colville Confederated Tribes followed by expressions of opposition from local JOM parent committees.

18. Indian Self-Determination and Education Assistance Act, $\S 203,88$ Stat. 2214 (Jan. 4, $1975)$.

19. The report, entitled "Study of Title II of P.L. 93-938," was actually prepared by contract with the National Indian Education Association.

20. Pub. L. No. 93-580, 88 Stat. 1910 (Jan. 2, 1975).

21. Statistics on Indians and Indian education are notoriously inaccurate, partially because there is no commonly accepted definition of the term "Indian." The general figures used in this article are extrapolations from inconsistent data published by the Bureau of Indian Affairs and the United States Office of Education.

22. See, e.g., Squire v. Capoeman, 351 U.S. 1, 9 (1956) (recognizing the tax-exempt status of tribal and restricted Indian lands). See generally Israel \& Smithson, Indian Taxation, Tribal Sovereignty and Economic Development, 49 N. DAK. L. REv. 267 (1973).

23. House Comm. on Educ. and Labor, Elementary and Secondary Education Amendments of 1974, H. R. REP. No. 805, 93d Cong., 2d Sess. 14 (1974). 
tary and Secondary Education Act of $1965,{ }^{24}$ is limited to persons who are "educationally deprived," and thus includes both reservation and nonreservation Indian children among the participants. Exclusive benefits are provided Indian children by the Indian Education Act of 1972 (IEA) ${ }^{25}$ and the Johnson-O'Malley Act of 1934 (JOM). ${ }^{26}$ The IEA, funded at forty-two million dollars in fiscal year $1975,{ }^{27}$ provides for entitlement grants to public school districts enrolling Indian children for supplemental programs, certain discretionary grants, and adult education funds. The main thrust of the broadscale Johnson-O'Malley program in recent years has been to provide supplemental programs to meet the special educational needs of Indian children in public schools. ${ }^{28}$ In fiscal year $1975 \mathrm{JOM}$ was funded at twenty-eight million dollars. ${ }^{29}$ All of the federal programs are available to reservation school districts but only Title I and the IEA serve non-reservation Indians.

In evaluating each of these programs it is necessary to pose several important questions: (1) how do these programs operate in practice; (2) to what extent do they result in duplication of benefits or inefficiency in administration; and (3) what legislative or administrative changes, if any, would render them more effective.

\section{BASIC SUPPORT}

Districts enrolling Indian children, like most of the nation's school districts, are experiencing difficulty in generating sufficient funds for the operation and maintenance of the basic school program. Some contributing factors such as inflation and increased taxpayer militance are nationwide phenomena. In addition, most of the Indian districts are in rural portions of states that have fewer resources to expend on education than the national average. ${ }^{30}$ Finally, federal agencies have begun to enforce more rigorously regulations

24. 20 U.S.C. $\$ 241(1970)$. The Title I program was extended by Congress for an additional five years by the Education Amendments of 1974, Pub. L. No. 93-380, 88 Stat. 484 (Aug. 21, 1974).

25. 20 U.S.C. $\S \S 241$ aa, 887 c, 1211 a (Supp. III, 1974).

26. 25 U.S.C. $\$ \$ 452-55(1970)$.

27. Hearings on Dep't of the Interior and Related Agencies Appropriations for 1976 Before a Subcomm. of the House Comm. on Appropriations, 94th Cong., 1st Sess., pt. 3, at 327 (1975) [hereinafter cited as FY 1976 House Appropriations Hearings].

28. See Testimony of Morris Thompson, Comm'r of Indian Affairs, in FY 1976 House Appropriations Hearings 61 . In fiscal 1975, 75 per cent of JOM monies were spent for supplemental programs. $I d$.

29. FY 1976 House Appropriations Hearings 56.

30. In 1973 the following states with significant Indian populations spent less than the nationwide median of $\$ 810$ for the education of each pupil: Arizona (\$771), Idaho (\$629), Maine $(\$ 739)$, Nevada (\$799), New Mexico (\$732), North Carolina (\$668), North Dakota (\$719), Oklahoma $(\$ 660)$, and South Dakota $(\$ 760)$. U.S. Office of Education, The Indian Education Act of 1972: Report of Progress for the First Year of the Program Table 2 (1974). 
which prohibit the use of federal supplemental funds for basic support. ${ }^{31}$ This federal action so acutely affects predominantly Indian districts that the problem has been brought to the attention of Congress. ${ }^{32}$

Legally, the states, rather than the federal government, have the duty to provide education services for Indian children. The Supreme Court has ruled emphatically that the opportunity for public education, "where the state has undertaken to provide it, is a right which must be made available to all on equal terms." 33 Indian children, as citizens of the state in which they reside, are entitled to a free public education to the same extent as other citizens. ${ }^{34}$ It has long been held by both state ${ }^{35}$ and federal ${ }^{36}$ courts that the provision of Indian schools by the Bureau of Indian Affairs does not justify the exclusion of Indian children from public schools. Nor do the Indian treaties impose on the federal government a generalized responsibility for the education of Indian children. ${ }^{37}$

Many persons from states with large Indian populations, incorrectly believing that the federal government is responsible for the education of Indians, ${ }^{38}$

31. Widespread misuse of federal funds in Indian school districts was documented in AN Even Chance 2-4. Subsequently, a federal court held that Title I and Johnson-O'Malley funds could not be used for basic support. Natonabah v. Board of Educ., 355 F. Supp. 716 (D.N.M. 1973). These events, accompanied by heightened community awareness, received attention from the United States Office of Education and the Bureau of Indian Affairs. In the case of BIA, the JOM regulations were revised and tightened. See discussion in text accompanying notes 107-57 infra.

32. Indian Self-Determination and Education Assistance Act, $\S 203(2)(\mathrm{A}), 88$ Stat. 2214 (Jan. 4, 1975).

33. Brown v. Board of Educ., 347 U.S. 483, 493 (1954) (emphasis added); Rosenfelt, supra note 5, at 502-06; $c f$. Letter from John Kyl, Assistant Secretary of the Interior to Henry M. Jackson, Chairman, Committee on Interior and Insular Affairs, Aug. 3, 1973, in Hearings on $S$. 1017 Before the Subcomm. on Indian Affairs of the Senate Comm. on Interior and Insular Affairs, 93d Cong., lst Sess. 85-86 (1973). Assistant Secretary Kyl's letter appears to make the following points: (1) Legal responsibility for the education of Indian children rests with the states; (2) the acutal responsibility is exercised by both entities (state and federal) "in certain complicated ways"; (3) because it is "difficult" to educate Indian children, the federal government has a "moral" responsibility to help the states.

34. Some Indians did not become citizens until the Citizenship Act of 1924, ch. 233, 43 Stat. 253 (codified in 8 U.S.C. $\S 1401(\mathrm{a})(2)(1970)$ ). Others had become citizens through treaty or the General Allotment Act of 1887. Responsibility for the education of non-citizen Indians rested with the federal government. The shift in responsibility from the federal government to the states 15 discussed in Rosenfelt, supra note 5, at 492-506. The lingering questions concerning responsibility for Indian education are traceable in part to this historical background.

35. Grant v. Michaels, 94 Mont. 452, 23 P.2d 266 (1933); Piper v. Big Pine School Dist., 193 Cal. 664, 226 P. 926 (1924); Crawford v. District School Bd., 68 Ore. 388, 137 P.217 (1913).

36. United States v. Dewey County, 14 F.2d 784 (8th Cir. 1926), aff'd sub nom. Dewey County v. United States, 26 F.2d 434 (8th Cir. 1928), cert. denied, 278 U.S. 649 (1928).

37. See Rosenfelt, supra note 5 , at 492-93, 503. The provision of education may, however, be required as part of the broad federal trust responsibility to the Indians. See Chambers, Judicial Enforcement of the Federal Trust Responsibility to Indians, 27 STAN. L. REv. 1213, 1243-46 (1975).

38. E.g., Senator Paul Fannin is perhaps the most influential person who espouses this view. In Hearings on $S .1017$, supra note 33, at I60-61, he stated that, "It is my opinion that the Federal Government has full responsibility for financing the education of those Indian children whose parents reside on reservation land." Senator Fannin's position, set forth more fully in SENATE Comm. ON Interior and Insular Affairs, Indian Self-Determination and Education As- 
resent the expenditure of local funds for the education of Indians and often defeat school bond levies which would benefit Indian students. ${ }^{39}$ Furthermore, both state and federal education officials, responsive to the popular confusion of this issue, countenance disparities in educational programs provided to Indians by state and local government which exceed most of the overt discrimination formerly practiced against blacks in the deep South. ${ }^{40}$ It is important, therefore, to indicate how federal assistance more than compensates for the burden placed on local districts and how the structure of federal programs bears on the overall problem of basic support.

\section{A. Public Law 81-87441}

Indian children generate P.L. 874 money for public school districts because their parents live and work on property held in trust by the federal

Sistance Act, S. ReP. No. 762, 93d Cong., 2d Sess. 30 (1974), is to the effect that where the taxexempt status of Indian lands makes it impossible for a local school district to generate enough monies to operate an adequate educational program, the federal government is obliged to supply necessary funds.

39. See, e.g., Testimony of Myron Jones in Indian Education Act of 1971, in Hearings on H.R. 8937 E S. 2482 Before the General Subcomm. on Education of the House Comm. on Education and Labor, 92d Cong., 2d Sess. 163-64 (1972).

40. The most striking evidence of the toleration of blatant disparities related to race occurs in the failure to provide adequate school facilities to house Indian students. In the State of Alaska, for example, 135 predominantly Native villages lacked any secondary school facilities as of October 5, 1972, while all but ten predominantly white settlements had such facilities. A portion of the litigation initiated by Alaska Natives to rectify this disparity is reported in Hootch v. Alaska State Operated School System, 536 P.2d 793 (Alas. 1975). In the Gallup-McKinley school district in New Mexico, a federal district court concluded that the local school district had allocated school construction monies in a manner which denied "a fair share (indeed, any real share at all) to those schools with overwhelmingly Indian enrollments." Natonabah v. Board of Educ., 355 F. Supp. at 723. The southern portion of Utah's San Juan school district includes the Navajo Indian Reservation where more than 50 per cent of the district's pupils reside. The district's two secondary schools are located many miles to the north in the towns of Monticello and Blanding. Most Indian children who wish to attend secondary school must be bused distances over one hundred miles each day. After Navajo parents brought suit, the district agreed to construct additional schools on the reservation. Sinajini v. Board of Educ., Civil No. 74-346 (D. Utah, consent decree Aug. 15, 1975), in 2 Indian L. Rep. no. 12, at 9 (1975).

In each of these three instances, Indian parents were forced to retain attorneys in attempting to rectify practices which were clearly discriminatory. Not until federal, state, and local education officials were confronted with the facts in litigation were meaningful efforts toward corrective actions undertaken.

Nor are the disparities in the examples given above limited to building facilities. In Alaska during FY 1972, the state legislature appropriated 37 per cent less state money for the educational program in the district with the largest Native enrollment than the state-wide average. In the Gallup-McKinley district, the federal court found disparities in the allocation of equipment, instruction expenditures, operational expenditures, and misuse and misallocation of JOM and Title I funds, all to the detriment of Indian students. In the San Juan school district in Utah, an out of court settlement of the litigation required the district to institute the kind and type of bilingual program now mandated by civil rights statutes. See, e.g., 20 U.S.C.A. $\$ 1703$ (c) (Su pp. 1976).

41. Act of Sept. 30, 1950, Pub. L. No. 81-874, 64 Stat. 1100, as amended, 20 U.S.C. $\S \S 236-41-1$ (1970). This law, the Federally Impacted Areas Act, together with the School Facilities Construction Act, 20 U.S.C. $\$ \S 631-47$ (1970), are commonly referred to as "Impact Aid" laws. See generally U.S. Dep't of Health, Education and Welfare, Administration of Public 
government. Although the original impetus for the Impact Aid program resulted from the defense activities of the federal government, the federal trust and tax-exempt status of Indian lands warranted inclusion of Indians in the program. ${ }^{42}$ While Indians attract a mere five per cent of the annual P.L. 874 appropriation of $\$ 600$ million, ${ }^{43}$ the $\$ 31,137,000$ allocated to school districts encompassing Indian reservations constitutes the most important single source of revenue for many of those districts. These monies are unrestricted, and they sometimes amount to as much as 40 to 60 per cent of the total operational budget of a reservation school district. ${ }^{44}$ The Indian-controlled Rocky

Laws 81-874 \& 81-815, Twenty-Third Annual Report of the Comm'r of Education (1975).

P.L. 874 is designed to assure that a federal connection, such as living on tax-exempt Indian land, will not cause any financial burden to local school districts. Payments are computed by multiplying the number of children whose parents live on Indian land by the amount which "comparable" school districts spend per pupil from local sources. Additional funds are provided where parents work but do not live on Indian land. In the event that the sum received by the district is not enough to provide a level of education equivalent to that maintained in comparable districts or if there are unusual geographical features in a district which affect the cost of education, the Commissioner of Education is authorized to make necessary adjustments.

42. Rosenfelt, supra note 5, at 497-99; see An Even Chance 1-10.

43. Cf. Hearings on Dep't of Labor and Health, Education and Welfare Appropriations for 1976, Before a Subcomm. of the House Comm. on Appropriations, 94th Cong., 1st Sess., pt. 5, at 269 (1975); FY 1976 House Appropriations Hearings 342.

44. A representative sample of predominantly Indian districts as reported in TWENTY-THIRD Annual Report of the Comm'r of Education, supra note 41, Table 1, at 28 shows the following:

State \&

District

Arizona

Window Rock

Chinle C.S.D. No. 24

Peach Springs S.D. No. 8

Kayenta E.S.D. No. 27

Minnesota

Red Lake I.S.D. No. 38

Montana

Browning E.S.D.

Elem S.D. No. 87

New Mexico

Gallup-McKinley

I.S.D. No. 22

Cuba

North Dakota

New Town

South Dakota

Shannon I.S.D. No. I

Todd County I.S.D.

\section{Net Payment \\ Estimated \\ $1972-73^{*}$}

$14,527,743$

904,852

$1,205,710$

46,036

305,142

$3,505,450$

449,143

$6,019,439$

655,856

172,573

$14,667,549$

$2,995,331$

I,602,780

251,120

$4,784,078$

100,461

$5,732,911$

709,324

667,760
Current

Expenditures $\dagger$

$299,846,649$

$2,527,421$

$2,886,103$

97,305

$1,037,343$

427,$133 ; 123$

$1,087,039$

$93,529,336$

$1,461,806$

379,212

$182,185,419$

$11,500,000$

$5,100,000$

786,100

$57,636,379$

172,734

$62,356,889$

$1,198,000$

$1,313,300$

Per cent**

* Includes revenue from three sections of P.L. 874, $\S 2,3,4$, as amended, 20 U.S.C. $\S \S 237-39$ (1970).

$\dagger$ Total operational expenditures

** Calculated by author 
Boys School Board of Montana did not exaggerate when it explained to a congressional committee: ${ }^{45}$

P.L. 874 funds are the life blood of Reservation schools. To date, P.L. 874 has been a remarkably stable source of funding. Funding has been stable because impact aid, going to school districts in 375 Congressional Districts, has a powerful constituency and strong political appeal. The funding of the Reservation schools is relatively secure because-and probably only because-each Congressman and Senator, in voting the interests of his own constituents, at the same time, perhaps unwittingly, votes the interests of the Reservations.

There is good reason to continue funding P.L. 874 for children living on Indian reservations. Although reservation Indians pay no real property taxes, their status as citizens entitles them to educational services. Without P.L. 874 the education of Indian children would place a financial burden on local school districts. Because the location of Indian reservations within one state rather than another may be viewed as fortuitous, it seems appropriate that taxpayers from all the states should contribute to the expenses of educating reservation Indians. In this sense Indian reservations are analogous to other federal installations.

Although P.L. 874 does not directly compensate state government for their contributions to Indian education and although Indians living on trust land pay no state income tax on earnings from Indian land, it does not follow that the states suffer a financial burden requiring additional federal relief as a consequence of Indian education. Indian people, tribal governments, and reservation economic enterprises generate considerable taxable wealth to the states. Mining, tourism, manufacturing, governmental services, conventions and the like all result in substantial taxable income to state government. This Indian contribution to the state's economy is rarely acknowledged when state officials complain about the indisputably high cost of rural (Indian) education. If all factors were considered, no state government could demonstrate a net loss of tax revenue due to the unique status of Indian reservation land.$^{46}$

45. Education Amendments of 1971, Hearings on S. 659 Before the Subcomm. on Education of the Senate Comm. on Labor and Public Welfare, 92d Cong., 1st Sess., pt. 4, at 1784 (1971).

46. Two recent judicial opinions contain data which are instructive. In Prince v. Board of Educ. N.M. _ 543 P.2d 1176 (1975), non-Indian taxpayers unsuccessfully challenged the right of Indians residing on tax-exempt land to vote in school board and school bond elections, and to have proceeds from school bonds used to construct schools on the reservation. The Supreme Court of New Mexico found that almost 97 per cent of the taxable wealth of the district was located on the Navajo reservations on land leased from the tribe by corporations. Although the land itself is not taxable, the corporate buildings and property are assessed as taxable personal property. In Confederated Salish \& Kootenai Tribes v. Moe, 392 F. Supp. 1297 (D. Mont. 1975), aff'd, $96 \mathrm{~S}$. Ct. 1634, 1645 (1976), a three-judge federal court held the imposition of a state cigarette tax on reservation smoke shops invalid. In response to the argument that Indians who receive the benefits of state citizenship must accept the tax burdens as well, the court examined data on the economic contributions made to the state and counties by the tribes and the federal government. It found that "(a) the amount contributed by the Federal Government is substantial; (b) the funds expended by both the Federal Government and Tribes contribute to the economic 


\section{B. Equitable Distribution of Funds}

Disparities exist within, as well as between, schools and school districts educating Indian children. Within districts with racially identifiable schools, disparities will often be found in the services provided and expenditures allotted. Sometimes a hint of these disparities can be gleaned from the Title I comparability report, ${ }^{47}$ but more often a rather thorough audit is required to ferret out the necessary data. The most conspicuous disparity, however, cannot be hidden: the quality of school facilities serving Indian children will almost invariably compare unfavorably with facilities serving non-Indians. Even when the predominantly Indian schools are new, they tend to be overcrowded and lack adequate supporting facilities such as cafeterias, gymnasiums, restrooms, and vocational education shops. ${ }^{48}$

The time has come to confront directly this clear discrimination against Indian children. For many years, the federal government has expended everincreasing sums of money to assist the education of Indians and in so doing it has unwittingly subsidized racial discrimination. ${ }^{49}$ The easiest way to eliminate this discrimination is to direct the United States Office of Education's Office of Civil Rights to conduct a compliance review of each district and each state

well being of the Reservation, and (c) non-Indians benefit from at least part of the expenditures." 392 F. Supp. at 1314-15. The court was not, however, able to determine if the state or local governments suffered any net tax loss.

47. In order to receive Title I funds, the local education agency must submit a report which includes data prescribed by 45 C.F.R. $\$ 116.26$ (1975) which demonstrates that state and local funds allocated to Title I schools are comparable to funds allocated to non-Title I schools. The purpose of this requirement is to assure that Title I funds can be used to meet the special educational needs of educationally deprived children and are not used to "supplant" (take the place of state and local funds.

48. See note 40 supra. Natonabah v. Board of Educ., 355 F. Supp. 716 involved a school district consisting of thirteen schools which were predominantly Indian and twelve schools predominantly non-Indian. The evidence showed that 24.9 per cent of the Indian students attended classes in portable or makeshift classrooms compared to 11.7 per cent of non-Indians attending school under similar circumstances. There was an 18 per cent disparity in the value of the buildings which Indians attended compared to those attended by non-Indians. These disparities were held to constitute racial discrimination.

The discussion here focuses on disparities in the allocation of resources. Other types of racial discrimination beyond the scope of this article but regularly found in Indian public school districts include: failure to provide a bilingual/bicultural curriculum, see Lau v. Nichols, 414 U.S. 563 (1974); misclassification of Indians as educationally mentally retarded, see, Kirp, Schools as Sorters: The Constitutional and Policy Implications of Student Classification, 121 U. PA. L. Rev. 705 (1973); and uneven application of suspension and expulsion sanctions, see Hawkins v. Coleman, 376 F. Supp. 1330 (N.D. Tex. 1974); Yudof; Suspension and Expulsion of Black Students from the Public Schools: Academic Captial Punishment and the Constitution, 39 LAw \& CoNTEMP. ProB. no. 2, at 374 (1975).

49. Where the state and/or the local school district fails to provide Indians with sufficient educational services or facilities to meet minimum standards, federal aid programs such as Johnson-O'Malley and Public Law 81-815 have been used to make up some of the difference. These federal subsidies reward those districts which provide least assistance to Indians. In practice, little effort is made to separate those states and districts which are unable to provide necessary educational services from those which are unuilling to do so. In each of the many instances where the amount of state or local resources provided for Indians is less than that provided to others, racial discrimination exists. $C f$. Natonabah v. Board of Educ., 355 F. Supp. 716. 
enrolling Indian students which receives P.L. 874 funds on their account. Where violations are found the district or state should be required to prepare a plan designed to eliminate the discrimination within a time frame acceptable to both the Office of Education and the Indian tribe whose members are affected. In the event agreement cannot be reached, P.L. 874 funds should be withheld and the Department of Justice should be instructed to institute suit against the state and district in question to compel the reallocation of state monies to compensate for the withheld federal monies.

\section{Interdistrict Disparities}

Interdistrict funding disparities are no less critical. Districts enrolling reservation Indian children have long been faced with a chronic inadequacy of monies to support basic school programs. ${ }^{50}$ All too often the Indian children have been blamed for an inequity caused by state systems of school finance which make revenue a function of the taxable wealth of the local school district. More than a dozen states have overhauled school finance laws based on property taxes in order to achieve greater equity between school districts. ${ }^{51}$ The President's Commission on School Finance recommended a federal incentive grant program to induce the states to assume responsibility for the full funding of equitable state education programs. ${ }^{52}$ The cost of eliminating the disparities, estimated by the Commission at four to five billion dollars, may explain why thus far no action has been taken.

Although Indian education may not be a sufficiently broad issue to warrant the imposition of new finance schemes in all states, there is a more limited approach which may well be feasible for districts educating reservation Indian children. These districts receive P.L. 874 monies. Until the 1974-1975 school year, states which provide "equalization" 53 monies to local districts were not permitted to consider federal impact aid monies in calculating entitlements of the districts for equalization funds. ${ }^{54}$ In 1974 , however, in order to

50. Testimony of Herbert Jacobson, Planning Officer, Office for Indian Education, in $F Y$ 1976 House Appropriations Hearings 307-08; cf. Additional Views of Senator Paul Fannin, in S. REP. No. 762, supra note 38 , at 30 . A thorough study comparing the amount of monies available for basic support to public school districts educating Indians with statewide or national averages has not been published.

51. See 2 Education Comix of the States, Major Changes in School finance: Statehouse Scorecard (Res. Brief No. 2, 1974).

52. President's Commix on School Finance, Schools, People, \& Money, The Need for Educational Reform, Final Report 36-37 (1972).

53. Equalization monies are those provided by a state to local school districts in order to make each district equally able to support some level of education expenditure predetermined by the state. The amount of equalization monies allocated to local districts is inversely proportional to the taxable wealth of the district. Almost all states provide some form of equalization assistance.

54. 20 U.S.C. $\$ 240 d$ (1970); Carlsbad Union School Dist. v. Rafferty, 300 F. Supp. 434 (S.D. Cal. 1969); Hergenreter v. Hayden, 295 F. Supp. 251 (D. Kan. 1968); Douglas Independent School Dist. No. 3 v. Jorgenson, 293 F. Supp. 849 (D.S.D. 1968); Shepheard v. Godwin, 280 F. 
encourage the states to distribute more equalization funds, Congress amended P.L. 874 to permit funds under that Act to be taken into account in computing entitlements for state equalization funds. ${ }^{55}$

Congress should further amend the statutes to provide that in districts where more than ten per cent of the enrollment consists of Indian children living on tax-exempt land, P.L. 874 payments may be considered for state equalization purposes only if funds available for basic support from state and local sources equal one hundred dollars or more per pupil above the state average. ${ }^{56}$ Such a standard would not require states to fund Indian districts at one hundred dollars above the state average; rather, it would prohibit states from considering P.L. 874 monies for state equalization purposes unless the requisite standard was met. It bears some emphasis that until the 1976 fiscal year, states could not consider P.L. 874 revenue at all in their allocation of equalization funds. The effect of this proposal would be modest, but it would increase the flow of basic support funds to those districts most in need. ${ }^{57}$

In order to assure sufficient operating funds for public schools on or near Indian reservations, federal policy should, therefore, be based on three elements: (1) P.L. 874 monies should continue to be appropriated so that the taxexempt status of Indian land does not constitute a financial burden to local school districts; (2) racial discrimination against Indian students by public school districts should be identified, acknowledged, and rooted out; and (3) the federal government should exercise the leverage afforded by P.L. 874 to require states to allocate a fair share of education monies to local school districts which educate Indian children. In this manner schools and school districts educating Indian children can receive a more equitable allocation of funds for general operating expenses without increased federal expenditures. Federal monies can then be concentrated in those areas where the states and local school districts must have federal financial assistance to provide an exemplary education for Indian children.

II

\section{School Construction Programs}

The most immediate financial problem in Indian education today is the shortage of school construction funds. ${ }^{58}$ In 1953, when the government

Supp. 869 (E.D. Va. 1968); see Note, The Dilemma of Federal Impact Area School Aid, 55 MinN. L. REV. 33 (1970).

55. 20 U.S.C. $\S 240(\mathrm{~d})(2)(1970)$.

56. More precisely, separate computations should be required for elementary and secondary school expenditures.

57. By increasing support for both Indian and non-Indian students, a contribution might also be made to the reduction of friction between the races in districts encompassing Indian reservations.

58. Construction Assistance for Indians under P.L. 815 amounted to $\$ 5,528,000$ in 1973 , $\$ 11,200,000$ in 1974 , and $\$ 10,500,000$ in 1975. FY 1976 House Appropriations Hearings 327 . As of 
sought to transfer Indian students to public schools as part of the policy of "termination" of the special status of Indians, Congress amended the School Facilities Construction Act (Public Law 81-815) to provide construction funds for public schools attended by Indians. ${ }^{59}$ There are two ways school districts can qualify for P.L. 815 funds. If one-third of the student population or region served is Indian, districts can receive construction funds if they show that they are making an effort to raise money through tax programs or other financial means and have insufficient funds to provide facilities to their students. If these conditions are met, funds may be used for any school in the district, even those that serve no Indian students. Alternatively, districts with as little as a 10 per cent Indian enrollment or land base may qualify under the statute without a showing of additional financial effort or insufficiency of funds. Districts qualifying under this provision, however, may only apply funds received to those schools in the district actually serving Indian students or reservation areas. ${ }^{60}$ Ironically, the first provision, section 14(a), is not objectionable even though it is possible that none of the federal monies will be spent on schools for Indians. To qualify for 14(a) funds a district must have allocated all its construction funds on an equitable basis and utilized available local resources including bonding authority to serve all students. If such a district still finds itself unable to raise sufficient construction monies because of the tax-exempt status of Indian land, then the federal government should provide additional assistance.

By contrast, districts receive section 14(b) funds without any showing of reasonable diligence to utilize other resources and without any showing of financial need. Section 14(b) seems to imply that a local district is free to discriminate against Indians by allocating state and local construction monies for facilities serving non-reservation students and awaiting federal funds for the construction of schools serving the reservations. All too often this is precisely what occurs. ${ }^{61}$

The principle of equal educational opportunity is too important to be further ignored. Congress should require all qualifying districts to demon-

\footnotetext{
June 20, 1974 the backlog of eligible but unfunded applications for construction under P.L. 815 for districts serving Indian children amounted to $\$ 39,607,624$. Hearings on Dep't of Labor and Health, Education and Welfare Appropriations for 1976, supra note 43, at 262. This represents a small portion of the total construction need which in the most comprehensive survey was estimated to be in excess of $\$ 163,000,000$. See generally F. Mckinley, Public School Survey of Construction aid Needs Related to the Education of Reservation Indian Children (1972). This study examined the construction needs of 162 school districts in 21 states which enroll reservation Indian children.

59. 20 U.S.C. $\$ 631-47$ (1970). By the Act of August 8, 1953, ch. 400, § 1, 67 Stat. 526, Congress expressly provided for assistance $t)$ districts whose ability to finance needed construction was impaired on account of the immunity from taxation of Indian lands. These provisions now appear at 20 U.S.C. $\$ 644(1970)$.

60. 20 U.S.C. $\$ \S 644(\mathrm{a}), 644$ (b) (1970). Ser also 45 C.F.R. \$114.16 (1975),

61. See, e.g., Natonabah v. Board of Educ., 355 F. Supp. at 721-22.
} 
strate that funds have been distributed equitably and that available local resources, including bonding authority, are inadequate for the needs of all students in the district because of the tax-exempt status of Indian land. In the case of the many districts guilty of past discrimination against Indians, federal grants should be converted to loans, with funds being repaid from state and local revenues. Furthermore, local districts that refuse to provide adequate facilities for the education of Indians should, if necessary, be compelled by the courts to make necessary expenditures. ${ }^{62}$

Beginning in 1970, Congress took action designed to provide increased federal construction funds for reservation Indian school districts. It amended P.L. 815 to place Indian schools in the highest priority category together with military bases and natural disasters. ${ }^{63}$ The new Indian Education Assistance Act of 1975 provides an additional federal source for school construction monies. ${ }^{64}$ Since 75 per cent of these funds must be allocated on the basis of priorities established under section 14 of P.L. 815 , it is apparent that in this instance Congress deliberately intended to duplicate an existing federal program to provide a mechanism for increasing appropriations. The remaining 25 per cent of the funds under the new act may be spent to assist tribes in constructing facilities for schools they control, but this latter provision is limited to "previously private" schools. ${ }^{65}$ The statute should be amended to allow a wider range of eligibility ${ }^{66}$ and to enable the Bureau of Indian Affairs to make grants to public school districts that are effectively excluded by the rigid guidelines and priorities of P.L. $815 .{ }^{67}$

62. See Griffin v. County School Bd., 377 U.S. 218 (1964); Sinajini v. Board of Educ., in 2 INDIAN L. REP. no. 12, at 9 (1975).

63. 20 U.S.C. $\$ 644(c)(1970)$.

64. Pub. L. No. 93-638, § 204(b), 88 Stat. 2215 (Jan. 4. 1975).

65. Id. $\$ 208$ provides in part: "The Secretary is authorized and directed to provide funds, pursuant to this Act. . . to any tribe or tribal organization which controls and manages any previously private school." Id. \& 204(c) provides: "The Secretary may expend not more than 25 per centum of such funds... on any school eligible to receive funds under section 208 of this Act." The limitation to "previously private" schools appears to have been deliberately imposed by the House which eliminated broader language contained in the Senate-passed bill. Compare S. REP. No. 762, supra note 38, at 15 with H. REP. No. 1600. 93d Cong., 2d Sess. 18 (1974). The Department of Interior opposed provisions in the Senate bill which would have permitted the Secretary of Interior to have broad authority to assist public school districts serving Indian children on the ground that such authority would duplicate the program administered under Pub. L. No. 81-815, 64 Stat. 967 (1950). Letter from John Kyl to James A. Haley, May 17, 1974, in H. REP. No. 1600 , supra at 36 .

66. Former BlA schools now operated by tribal organizations are not eligible for funds under this regulation. See 40 Fed. Reg. 51283 (Nov. 4, 1975).

67. For example, there are several public school districts, notably in Alaska, which educate large numbers of Indians and have urgent construction needs but do not qualify under existing priorities. The priority system for approval of P.L. 815 projects is based on the percentage of children living on tax-exempt land in the district and the percentage of children who are unhoused (i.e., without minimum school facilities) in the district. See 45 C.F.R. §§ 114.4, 114.5 (1970). The State of Alaska-with a large native population, high construction costs, and an almost total lack of secondary school facilities in predominantly native towns and villages-received 
III

\section{Supplemental Programs}

The Indian Education Act, Title I, and Johnson-O'Malley are the three programs which fund projects designed to meet the special educational needs of Indian children. There is some overlap in the objectives of these programs, but at present funding levels it is by no means clear that the overlap results in duplication of benefits or waste. The purpose of this section is to examine each program as it operates today, to assess the extent of overlap and duplication, and to suggest corrective actions which Congress and federal agencies might take to increase the efficacy and equity of educational services to Indian children.

This discussion proceeds on two assumptions. The first-thoroughly documented elsewhere-is that Indian children do have special educational needs which require compensatory programs. ${ }^{68}$ Indian boys and girls enter school on a par with children from other racial backgrounds, but with each advancing year Indian children as a group perform less well and by the time they reach secondary school age they drop out at an alarming rate. The purpose of the supplemental programs discussed below is to provide relevant programs geared to the needs of Indian children in the hope that this failure in the education system can be stemmed. The second assumption is that there is a great need for restraint by Congress in revising Indian education programs. Major needs in Indian education have been identified, legislation has been enacted, and projects throughout the nation are only now beginning to address the priorities set by Indian people. There is no indication that any of the existing supplemental programs for public schools is basically defective.

It is important to note that Indian people, for the first time, actively participated in the formulation and modification of the proposals which ultimately became the Indian Education Act of 1972, the 1974 Johnson-O'Malley regulations, and the Indian Self-Determination and Education Assistance Act. The programs which are in place today result from the incalculable investment of time and energy over a period of five years by Indian people in most of the major tribes and communities, and to a surprising extent these programs represent a consensus of collective Indian opinion. Radical changes by

\footnotetext{
a mere .9 per cent of the total section 14 funds appropriated from 1954 through 1973. It is not clear whether this is because (1) the state failed to apply, (2) Alaska Natives are not considered "federally connected," or (3) the availability of schools in the cities of Anchorage and Fairbanks and BIA facilities in Oklahoma and Oregon did not qualify native children as "unhoused." It is probable that construction needs for Alaska Natives exceed 50 per cent of the total needs of all other states at this time. See Hootch v. Alaska State Operated Schools, 536 P.2d 793 (Alas. 1975), discussed in note 40 supra. In contrast with Alaska, the State of Arizona received 34 per cent of all section 14 funds. Twexty-third Axvual Report of The Commo of Education, snpra note 41, at 130 .
}

68. See, e.g., authorities cited in notes 1 through 4 supra. 
Congress in the public school supplemental programs-at this early date - might be viewed as a breach of faith by Indian people. This discussion, then, is an attempt to identify aspects of existing programs which, if modified, might facilitate the more direct achievement of present goals and priorities.

\section{A. The Indian Education Act of 1972}

The Indian Education Act of $1972^{69}$ (IEA) is the most comprehensive federal program designed to meet the special educational needs of Indian children. With present funding levels at forty-two million dollars, IEA programs reach approximately 1,500 school districts in thirty-eight states and serve more than 250,000 Indian children enrolled in public schools. ${ }^{70}$ The statute defines "Indian" broadly, and contains no restrictions with respect to blood quantum or place of residence. ${ }^{71}$ The IEA is, therefore, the only Indian education program which serves the special educational needs of urban as well as reservation Indian children.

The Act establishes three broad programs. Part $\mathrm{A}^{72}$ provides categorical grants to local education agencies based on the number of Indian children enrolled and the average per pupil expenditure in the state. Funds must be spent to meet the special educational needs of Indian children for programs such as those providing bicultural and/or bilingual classes, culturally relevant curriculum materials, guidance, and counseling. ${ }^{73}$

69. 20 U.S.C. $\$ \$ 241$ aa, $887 \mathrm{c}, 1211$ a (Supp. II1, 1974).

70. FY 1976 House Appropriations Hearings 283-290.

71. 20 U.S.C. $\$ 1221 \mathrm{~h}$ (Supp. III, 1974) provides:

For the purposes of this title, the term "Indian" means any individual who (1) is a member of a tribe, band, or other organized group of Indians, including those tribes, bands, or groups terminated since 1940 and those recognized now or in the future by the State in which they reside. or who is a descendant. in the first or second degree, of any such member, or (2) is considered by the Secretary of the Interior to be an Indian for any purpose, or (3) Is an Eskimo or Aleut or other Alaska Native, or (4) is determined to be an Indian under regluations promulgated by the Commissioner, after consultation with the National Advisory Council on Indian Education, which regulations shall further define the term "Indian."

Present regulations merely repeat the statutory definition. 45 C.F.R. $\$ 187.2$ (1975).

72. 20 U.S.C. $\$ 241$ aa (Supp. 111, 1974).

73. Although Part $A$ is an "entitlement program," applications are not approved unless the local education agency complies with the statutory requirements for parent, community, and Indian involvement. Applicants for Part A funds must demonstrate that the proposed project has been developed:

(i) in open consultation with parents of Indian children, teachers, and, where applicable, secondary school students, including public hearings at which such persons have had a full opportunity to understand the program for which assistance is being sought and to offer recommendations thereon, and

(ii) with the participation and approval of a committee composed of, and selected by, parents of children participating in the program for which assistance is sought, teachers, and where applicable, secondary school students of which at least half the members shall be such parents.

20 U.S.C. $\$ 241 \mathrm{dd}(\mathrm{b})$ (B) (Supp. IIl, 1974) (emphasis added). In addition, the applications must set forth specific plans for operation, administration, and evaluation. 20 U.S.C. $\$ 24$ Idd(a) (Supp. 
It has been argued that federal funds should not be disbursed on a formula basis regardless of need but should be used to develop programs which can then be adopted and funded by local education agencies. ${ }^{74}$ However, it is important to remember that Part A serves Indian children who are not reached by any other Indian oriented education program. There are approximately 162 school districts in this country, located on or near Indian reservations, which educate a significant number of Indian students. ${ }^{75} \mathrm{But}$ approximately half of the 3,200 additional public school districts which are eligible ${ }^{76}$ to receive Part $\mathrm{A}$ funds have taken advantage of this program to identify the Indian children in their communities and to develop special programs for them. ${ }^{77}$ If Part A entitlements were not funded, it seems highly unlikely that districts with a small percentage of Indian students would perceive the special needs of that minority as warranting attention when competing requests from larger groups cannot be met. The entitlement aspect of Part A must, therefore, be continued if assistance is to reach non-reservation Indian students.

There are, however, two problems associated with Part A funding. First, the statute makes the level of funding dependent upon each state's average per pupil expenditure. ${ }^{78}$ The purpose of the provision is to take account of the variation in cost of delivery of educational services. Unfortunately, the variation among the states, ranging from a low in Arkansas of $\$ 578$ to a high in New York of $\$ 1549,{ }^{79}$ appears to reflect factors, such as the relative affluence of the states, which are unrelated to the actual cost of educational services. The Part A allocation formula should, therefore, be adjusted to pro-

III, 1974). In fiscal years 1973 and 1974 , almost 25 per cent of the applications submitted were denied by the Office of Indian Education for failure to comply with these requirements. U.S. OfFice of Education, supra note 30, at 13; FY 1976 House Appropriations Hearings 287. It appears, therefore, that there is a serious effort by the administrators of this program to prevent the misuse of funds so widespread in earlier education programs. See, e.g., AN Even Chance.

74. U.S. Commissioner of Education, John Ottina, advocated this position in the 1975 Appropriations Hearings but failed to persuade the Congressional Appropriations Committee. See FY 1975 House Appropriations Hearings 402-04.

75. Cf. synopsis of National Indian Training Research Center survey of construction needs of public school districts enrolling reservation Indian children in id. at 179.

76. Local education agencies are eligible for grants under Part A if they have ten Indian students or the Indian enrollment constitutes 50 per cent of the total enrollment. Every local education agency, however, which serves a single Indian child located in the states of Alaska, California, and Oklahoma or located on or near an Indian reservation is eligible. 20 U.S.C. $\S 241 \mathrm{bb}(\mathrm{a})(2)(\mathrm{B})$ (Supp. III, 1974). In practice, districts with negligible Indian enrollments do not apply for funds.

77. Statement of U.S. Office of Education, Office of Indian Education, in FY 1976 House Appropriations Hearings 287.

78. See 20 U.S.C. $\$ 241$ bb (Supp. III, 1974). By contrast, Title I allocations used the state average per pupil expenditures as a basis for computation only when the state average is higher than the national average. 20 U.S.C. $\$ 24 \mathrm{lc}(1970)$. Congress further refined the method of computation in 1974 by providing that the state average per pupil expenditure would be used so long as it was not less than 80 per cent nor more than 120 per cent of the national average. Education Amendments of 1974, § 103(a)(2), Pub. L. No. 93-380, 88 Stat. 484 (Aug. 21 , 1974).

79. U.S. Office of Education, supra note 30 Table 2, at 9. 
mote increased equity between the states. In 1974, Congress modified the Title I formula for precisely this reason, and now the state average per pupil expenditure is utilized only if it is not less than 80 per cent nor more than 120 per cent of the national average. ${ }^{80}$ In the case of Part $\mathbf{A}$ there is an additional consideration, not present in Title $\mathrm{I}$ : many of the eligible districts depend for a substantial part of their basic support on P.L. 874 which itself is distributed on the basis of per pupil expenditures of "comparable" districts within the state. The P.L. 874 formula works to the disadvantage of children from poor states and regions. The Part A allocation formula can be used to ameliorate the present disparities in resource allocation by substituting for the state average per pupil expenditure the national average figure. ${ }^{81}$

In addition to modifying the allocation formula, the present level of Part A funding must also be increased in order to operate meaningful education programs. In 1973, for example, the City of Cleveland, Ohio, received only $\$ 24,305$ to develop and operate a program for its 349 Indian students. ${ }^{82}$ In each of the last three years the number of eligible districts and the number of funded applications have risen at a faster rate than appropriations. ${ }^{83}$ The combination of increased Part $A$ appropriations and the reallocation of Title I funds, suggested below, would raise the IEA program to a size where it could have a meaningful impact.

Part $\mathrm{B}$ of the $\mathrm{IEA}^{84}$ authorizes discretionary grants to improve educational opportunities for Indian children. The statutory language is broad enough to cover almost any proposal relating to Indian education, and funded projects thus far emphasize teacher training, "alternative" schools for dropouts, curriculum development, and early childhood guidance and counseling ${ }^{85}$ Unlike Part A, eligible applicants under Part B include Indian tribes and organizations, BIA schools, institutions of higher education, and state and local education agencies. Applications submitted by Indian organizations receive priority under Part B except for training projects, and in that instance, projects which involve the training of Indians receive priority.

Since Part B is the only program which enables the concentration of substantial funds on a limited number of projects, there is no apparent overlap or duplication with other programs. In order for Part B to discharge its

80. See note 95 infra. See also H.R. ReP. No. 805, supra note 24 , at 13-14.

81. For the state of Alaska, which has a large native enrollment and which presently spends almost twice as much per pupil as the national average, special provisions would be required. Within that state, costs in isolated Eskimo villages are dramatically higher than in cities such as Ketchikan or Sitka. New York is the only other state which would be substantially and adversely affected by the proposed new formula.

82. FY 1975 House Appropriations Hearings 423.

83. FY 1976 House Appropriations Hearings 287.

84. 20 U.S.C. $\$ 887$ c (Supp. III, 1974).

85. See HEW News Release 3-12 (Aug. 12, 1974), listing Part B grant recipients and grant purposes. 
unique function, however, the program administration must be systematically scrutinized to insure that (1) resources are sufficiently concentrated on the few most meritorious projects, (2) unproductive and unsuccessful projects are not refunded, and (3) each project provides an appropriately detailed evaluation of its effectiveness in achieving its purposes. ${ }^{\mathbf{8 6}}$

Finally, Part $\mathrm{C}$ of the Indian Education Act authorizes grants to Indian tribes and organizations and to state and local agencies for programs of adult education. ${ }^{87}$ The most striking feature of Part $\mathrm{C}$ is its low level of funding: three million dollars in fiscal years 1974 and $1975 .{ }^{88}$ As recently as 1969 , the Senate's Special Subcommittee on Indian Education reported that forty thousand Navajo Indians, nearly a third of the entire tribe, are functionally illiterate in English and the average educational level of all Indians under federal supervision is five school years. ${ }^{89}$ Although adult education is widely acknowledged to be of prime importance, it has received comparatively little attention and inadequate funding. ${ }^{90}$ It would seem appropriate for an organization such as the National Advisory Council on Indian Education to conduct a review and an analysis to determine whether adult education is receiving the appropriate priority among Indian education programs.

\section{B. Title I}

A cornerstone of President Lyndon Johnson's War on Poverty, Title $\mathbf{I}$ of the Elementary and Secondary Education Act of $1965,{ }^{91}$ was the first and most significant federal aid program to recognize that economically and edu-

86. There is no reason to believe that Part B has been administered other than in the most exemplary manner. The concerns enumerated here arise from observations of tendencies exhibited by administrators of other federal programs. See, e.g., Testimony of Myron Jones, in Hearings on H.R. 8937 S S. 2482, supra note 39, at 167.

87. 20 U.S.C. \$ 1211 a (Supp. I11, 1974).

88. FY 1976 House Appropriations Hearings 296.

89. S. REP. No. 501 , supra note 1, at XII.

90. See, e.g., Special Education Subcomm., National Council on Indian Opportunity, The First Report to the President of the U.S., Between Two Milestones 87-90 (1972). There are two other federal programs, both funded through the states, which provide some assistance to Indian adults. The Adult Education Act of 1966 is designed to serve under-educated adults, primarily those with less than an eighth grade education. 20 U.S.C. $\& 1201$ (1970). The House Committee on Education and Labor recently reported evidence that for every dollar invested in these adult education programs, there has been a return to the government of more than eleven dollars in tax revenue resulting from increased earnings of students. H.R. REP. No. 805, supra note 24, at 66. Since the level of funding is based on population, states with large Indian populations such as Alaska, Arizona, Montana. New Mexico, North Dakota, and South Dakota each received less than $\$ 500,000$ per year in fiscal $1974 . \mathrm{Id}$. at $47-48$. Nationally, the Office of Education estimates that approximately $\$ 1,000,000$ under this act was spent on adult Indians. FY 1976 House Appropriations Hearings 347. The states receive larger grants through Part B of the Vocational Education Act, 20 U.S.C. $\$ 1241$ (1970). The Office of Education estimates that approximately four million dollars per year is spent to provide some vocational training to Indians of all ages. FY 1976 House Appropriations Hearings 346

91. 20 U.S.C. $\$ \$ 236-44$ a (1970). 
cationally deprived children may need compensatory educational programs in order to perform well in school.92 Although its overall success is unclear, Title 1 has performed one important function well: it provides substantial federal financial assistance to the public school districts with the greatest need. ${ }^{93}$ The overwhelming majority of this nation's public school districts received Title I funds amounting to a total of some $\$ 1.8$ billion in fiscal year $1975 .{ }^{94}$ Funds are dispersed by the United States Office of Education to the states which, in turn, approve, fund, and monitor projects proposed by local school districts for educationally disadvantaged children. The amount of Title I funds allocated to each local district is based on the number of its students from low income families and the state's average per pupil expenditure. ${ }^{95}$

Within a given school district, however, the "concentration" and "targeting" requirements of Title I operate to exclude many low income or disadvantaged children from Title I benefits. In order to insure that most of the children who receive Title I services are in fact poor, local school officials must select as target schools for Title I services those which have concentrations of children from low income families equal to or greater than the percentage of such children in the district as a whole. ${ }^{96}$ Children in non-target schools, in most instances, may not participate in the Title I program. ${ }^{97}$ In 1970 , only two-thirds of public school Indians attended Title I target schools. ${ }^{98}$ Within each target school, moreover, the Title I programs must be concentrated "on those children who are most in need of special assistance." 99 School administrators, therefore, are required to exclude some children in order to concentrate on the few most in need.

The kind and type of Title I program offered may not reflect the educational judgment of a school administrator so much as it reflects the wishes of the Parent Advisory Council (PAC). ${ }^{100}$ While the PAC is advisory in the sense

92. Cf. 20 U.S.C. $\S 241$ a (1970); S. ReP. No. 146, 89th Cong., lst Sess. 1 (1965).

93. H. REP. No. 805 , supra note 24 , at $4-7$.

94. Id. at 4 .

95. 20 U.S.C. § 24 lc (1970). In general terms, each school district's entitlement is computed by multiplying the total number of children from low income families (as defined by the Act) by 40 per cent of the state average per pupil expenditure provided the state average is not less than 80 per cent nor more than 120 per cent of the national average.

96. 45 C.F.R. \$ 116.17d (1975); U.S. Dep't of Health, Education, and Welfare, Office of Education, ESEA Title I (Program Guide No. 44, Guideline 1.1, 1969).

97. Cf. 45 C.F.R. \& 116.17a (1975), which authorizes an exception for educationally deprived children residing outside the project area "if such a participation will not dilute the effectiveness of the project with respect to children residing in the project area." In practice, the exception is rarely invoked.

98. Bureau of Social Science Research, Inc., Federal Funding of Indian Education: A Bureaucratic ENigma 53 (1973).

99. U.S. Dep't of Health, Education and Welfare, Office of Education, ESEa Title I (Program Guide No. 44, Guideline 4.2,4.7, 1969); cf. 45 C.F.R. $\S 116.17$ (c) (1975). Within the target schools, program participants are identified in terms of their educational needs and are not limited to children from poor families.

100. The Education Amendments of 1974, § 131, Pub. L. No. 93-380, 88 Stat. 479 (Aug. 21 , 
that it has no power to veto a decision of the school district, in some communities it plays a key role in setting priorities for the Title I program. In districts where Indians constitute the majority of Title 1 participants, the Title I PAC is likely to be composed largely of Indian parents and the priorities of the Title I program may correspond to the special educational needs of Indian students. ${ }^{101}$ Conversely, in many rural and almost all urban school districts, Indians constitute a small portion of the Title I students, and often the programs are designed to meet the needs of Chicano, black, or other children.

For all of these reasons, large numbers of eligible Indian children do not participate in Title 1 programs. ${ }^{112}$ When the Office of Education lists the many "Indian" education programs which it funds, it now acknowledges in a footnote that in the case of Title 1 "the dollars drawn to that district as a result of the presence of Indians do not necessarily benefit those Indians."103 Title I, then, is an example of inconsistency in federal programs with respect to Indian education. Although reservation Indian students generally benefit from Title I to a greater extent than urban students, there are many instances in which reservation children participate to a limited extent.

The advent of Part A of the IEA, a program similar to Title I and also administered by the United States Office of Education, may provide a mechanism through which the diversion of Title I benefits from Indian students could be curtailed. Quite simply, a portion of the Title I "Indian allocation" to each public school district could be transferred to the IEA Part A program and administered as part of it. ${ }^{104}$ A 50 per cent reallocation of each district's Title I "Indian" monies to Part A would produce a more equitable

1974), now require each local education agency to establish a district wide Title' I parent advisory council (PAC) and a PAC for each Title I target school. Title I parents must constitute a majority of PAC members, and the members must be chosen by parents in each school attendance area. The function of the PAC is to advise the local education agency in the planning. implementation, and evaluation of the Title I program. This amendment to Title I strengthens the present regulation which in 1972 made PACs mandatory. 45 C.F.R. $\$ 116.17$ (c) (1975).

In the early years of Title I, the parent advisory council was optional and in most districts existed, if at all, in name only. See AN Eves CHANCE 51-54. More recently, many school administrators have begun to accept the notion that parents should play a role in education policy, and parents themselves have become more determined to be heard.

101. In Indian communities perhaps more than others, the legitimacy and necessity of parent advisory councils is accepted. Under both Part A of the IEA and JOM, Indian parent committees analogous to the Title I PAC are more than advisory; they now have full veto power over the proposed program. 45 C.F.R. § 186.17(f) (1975); § 273.16(a)(2), 40 Fed. Reg. 51306 (1975).

102. Smith and Walker, in their study of federal funding of Indian education, cite unpublished U.S. Office of Education data showing that nationwide only 34 per cent of Indian students participate in Title I, supra note 9. See also AN Even Chance 39-40.

103. E.g., FY 1976 House Approprintions Hearings 330. Impact Aid is another program in this same category.

104. While there is presently no specifically designated Title I "Indian allocation" per se, local education agencies determine the number of low income students and the racial composition of Title I eligible children. Using these data, the "Indian allocation" of Title I monies can be readily determined. 
distribution of benefits with only a change in bookkeeping entries, and both programs would continue substantially as before. In this manner a greater percentage of funds received by the district because of the presence of Indian students would actually be spent for their benefit. The designation of Title I "target schools"105 should also be modified to reflect the reallocation of funds. ${ }^{106}$ This would allow some districts serving non-Indian disadvantaged children to offer Title I programs at previously ineligible schools.

In a handful of predominantly (more than 90 per cent) Indian school districts, the proposed reallocation of "Title I monies to Part A would effectively eliminate the Title I program. But because Indian children in each of these districts constitute more than 90 per cent of the students, the purpose of the Title I program (to provide compensatory education to educationally deprived children) and of the Part A program (to meet the special educational needs of Indian students) should in actuality be almost identical.

Neither the Indian Education Act nor its regulations contain language expressly excluding non-Indians from the Part A program. It would seem possible, therefore, to achieve a consolidation of the programs without creating administrative, ethical, educational, or legal nightmares. A "90 per cent Rule" could be adopted specifically for the 90 per cent Indian districts so that nonIndians would not be excluded from the program on the basis of race. Thus, if a remedial reading program were offered, students would participate based on educational need. Of course, if the district ran a bilingual program in Yupik Eskimo, a non-Indian child might be excluded because he lacked the special educational need that the program was designed to meet. The 90 per cent rule should result in increased administrative efficiency without diluting the "Indian" nature of the Part A program.

\section{The Johnson-O'Malley Act}

In 1934 Congress passed the Johnson-O'Malley Act (JOM), ${ }^{107}$ which contains broad authority for the Secretary of Interior to contract with states and

105. Title I target schools are those which have concentrations of children from low income families equal to or greater than the percentage of such children in the district as a whole. If, for example, 40 per cent of the children in the district are from low income families, then each school with a student body consisting of more than 39 per cent low income children will be a "target school."

106. This is necessary in order to prevent undue concentration of benefits to Indian students at Title I target schools at the expense of non-Indian students. To take an extreme and oversimplified example, assume a district consisting of two schools of equal size, $A$ and $B$. School $A$ has a 100 per cent Indian enrollment and 90 per cent low income children. School $B$ has no Indian enrollment, but 60 per cent of its students are from low income families. School $A$ is a Title 1 target school, School $B$ is not. Under the proposal, School $A$ will receive 66 per cent of all Title I funds through the reallocation to Part $A$, and if the "targeting" criteria are unmodified it will also receive the remainder of the funds directly through Title I. If, however, only 50 per cent of the Indian students were counted for targeting purposes, then School $B$ would be designated as a target school and would receive Title I funds. But if School $B$ had only 10 per cent low income children, then quite properly $\operatorname{School} A$ would continue to receive all the Title I funds.

107. 25 U.S.C. $\$ \S 452-54$ (1970). 
other entities for the education of Indian children. In order to encourage states to accept responsibility for Indian education, the Bureau of Indian Affairs, in the $1950 \mathrm{~s}$, promulgated a regulation which committed JOM funds "to accommodate unmet financial needs of school districts related to the presence of large blocks of non-taxable Indian-owned property in the district."108 Although the funds supplied under JOM and P.L. 874 were initially regarded as mutually exclusive, ${ }^{109}$ Congress amended the Impact Aid law in 1958 so that school districts could qualify for funds under both programs. ${ }^{110}$ The BIA then amended its regulations to provide that " $[w]$ hen school districts educating Indian children are eligible for Federal aid under Public Law $874 \ldots$ supplemental aid under [JOM] . . . will be limited to meeting educational problems under extraordinary or exceptional circumstances." 111 It seems apparent, then, that Congress intended P.L. 874 funds to provide general revenue "in lieu of taxes," while JOM monies were to be devoted to special programs for Indians. Only in extraordinary or exceptional circumstances might JOM monies be used for basic support. ${ }^{112}$

The BIA, however, failed to promulgate any standards or criteria by which the existence of extraordinary or exceptional circumstances could be ascertained. In practice the BIA often failed to administer the JOM program in any meaningful way, relying instead on the respective state departments of education. ${ }^{13}$ The states, however, frequently took the position that they were entitled to use JOM monies for any purpose not prohibited by the BIA. As a result, the following practices became common:

108. This provision was in force until 1974. The position that the BIA acted contrary to the intent of Congress in so limiting the JOM program is set forth in the Senate Subcommittee's Report on Indian Education, S. RE.P. No. 501, supra note 1, at 38-39. Ses also Sclar, Participation by Off-Reservation Indians in Programs of the Burean of Indian Affairs and the Indian Health Service. 33 Mont. L. Rev. 191, 210-11 (1972).

109. Act of Sept. 30, 1950, Pub. L. No. 81-874, § 2, 64 Stat. 1101; see Rosenfelt, supra note 5.

110. Act of Aug. 12, 1958, Pub. L. No. 85-620, $\$ 201(\mathrm{~b}), 72$ Stat. 559; see discussion in Rosenfelt, supra note 5.

111. 25 C.F.R. \$ 33.4(c), as amended, 40 Fed. Reg. 51282 (Nov. 4, 1975).

112. Section 20l(b) of P.L. 620 amended P.L. 874 to permit school districts to receive both JOM and P.L. 874 monies. The House Committee report sets out the intention of this anendment:

H.R. 11378 makes a significant change in the treatment of school districts educating Indian children. by enabling them to accept payments under Public Law 874 without forfeiting the right to obtain payments under the Johnson-OMalley Act for special services and for meeting educational problems under extraordinary or exceptional circumstances... H.R. 11378, in amending Public Law 874 in this connection, prevents any duplicate payments for the same services.

H.R. Rep. No. 1532, 85th Cong., 2d Sess. 3 (1958). Section 33.4(c) was promulgated contemporaneously and should have been read against this background. See Natonabah v, Board of Educ., 355 F. Supp. at 725-26.

113. Prior to 1970 . all JOM contracts were with state departments of education rather than with Indian uribes or organizations. The contracts consisted of approximately four pages with few provisions, other than verbatim repetitions of applicable federal regulations, limiting the use of funds. 
1) School districts used JOM monies as general aid, i.e., supplementing general operating funds and therefore ignoring special Indian education needs;

2) Indians had little voice in how JOM monies were spent;

3) JOM fund recipients were not held accountable and no evaluations were made to determine whether the money was being properly used;

4) the BIA failed to use its contracting authority with incorporated tribes and non-profit groups;

5) funds were allocated only to districts with large tax-exempt Indian reservations and allotments, while off-reservation districts with Indian children having special educational needs were ignored; and

6) the allocation of funds between and within states varied widely and followed no coherent or decipherable pattern. ${ }^{114}$

Indeed, until 1972, the BIA did not even require that JOM funds be kept separate from the general operating revenues of local school districts.

In the late 1960s and early 1970s pressure mounted from Indian interest groups $^{115}$ and congressional committees for the reform of the JOM regulations. In response, the $\mathrm{BlA}$ tightened the accounting procedures of the program and increased parent participation, ${ }^{116}$ but the promulgation of new regulations was stalled by old guard resistance within the BIA, pressures from some state departments of education, and divisions within the Indian community. ${ }^{117}$ Impetus for change was added when the District Court for

114. See Rosenfelt, New Regulations for Federal Indian Funds, 10 INEQUaLity in ED. 22 (1971); Testimony of Myron Jones and Sefferino Tenorio, in Hearings on H.R. 8937 i S. 2482, supra note 39 , at $137-75$.

115. These organizations included the Native American Rights Fund, the Harvard Center for Law and Education, Americans for Indian Opportunity, the NAACP Legal Defense and Education Fund, Inc, and the Institute for the Development of Indian Law. The single most effective group, however, was the National Indian Leadership Training (new Indian Education Training) of Albuquerque, New Mexico, headed by Myron Jones

116. Although the BIA has long been regarded by many as one of the most inept bureaucracies in the government, e.g., OUR Brother's KEEPER (E. Cahn ed. 1969), it nevertheless retains widespread support among Indian tribal people. To a considerable extent this support reflects approval of the BIA practices of consulting with and listening to representatives of Indian communities. When both S. ReP. No. 501, supra note 1, at 44 and AN Even Chance 51 criticized the BIA for failing to insure parent participation in the JOM program, the BIA set out to address that shortcoming and did so in relatively short order. See testimony of Morris Thompson, in Hearings on the Dep't of the Interior and Related Agencies Appropriations Fiscal Year 1975 , supra note 12 , at 1312 .

117. Fierce bureaucratic infighting occurred within the BIA between two factions. One group embraced most of the findings of the Senate Subcommittee and An Even Chance and eagerly sought reform of the JOM program. A second group appeared to act defensively concerning past $\mathrm{BIA}$ practices and seemed responsive to the positions of states and local school districts which argued forcefully for a continuation of JOM as basic support. Between 1972 and 1974, the BIA was almost institutionally incapable of reaching a decision on an issue such as this because (1) the position of Commissioner was vacant, (2) the administrative measures to implement Indian preference personnel policies within the bureau had caused divisiveness between white and Indian BIA employees which overshadowed most other issues, and (3) the national Indian community had not yet reached a position of unanimity regarding JOM. The principal issue which divided 
New Mexico ruled that the use of JOM monies for basic support by the Gallup-McKinley school district was illegal, ${ }^{118}$ and a consent decree in New Mexico bound the $\mathrm{BIA}$ to issue new regulations for use in that state. ${ }^{19} \mathrm{Fi}$ nally, in 1974, a group of thirty-eight Indian organizations presented an alternative set of regulations ${ }^{120}$ to those that had been developed by the Department of Interior. ${ }^{121}$ For perhaps the first time ever, a large number of diverse Indian organizations, working together to produce what they called the "Red Regs," virtually dictated to the Bureau of Indian Affairs a solution to a complex issue. Key members of Congress joined in support ${ }^{122}$ and the regulations, promulgated on August 21, 1974, contain the substance of the Red Regs. ${ }^{123}$

\section{New Regulations}

The 1974 JOM regulations made several basic changes in the program. Eligibility for benefits is no longer tied to residence on tax-exempt federal land; ${ }^{124}$ funds may be spent only for Indians and need not be spent in

the Indian community was whether off-reservation or urban Indians would be eligible for JOM funds.

118. Natonabah v. Board of Educ., 355 F. Supp. $716,725-29$ (D.N.M. 1973).

119. Denetclarence v. Board of Educ. of Independent School Dist. No. 22, Civil No. 8872 (D.N.M., filed Feb. 14, 1974), incorporating Agreement of Parties dated Dec. 14, 1973).

120. Participants included major national organizations such as the National Congress of American Indians, the National Indian Education Association, and the Coalition of Indian Controlled School Boards, as well as such important regional organizations as the Alaska Federation of Natives, the All-Indian Pueblo Council of New Mexico, and the Small Tribes of Western Washington. Attorneys from the Native American Rights Fund coordinated the effort.

121. 25 C.F.R. $\$ 33$ (1975), as amended, 40 Fed. Reg. 51282 (Nov. 4, 1975). The proposed regulations omitted many of the reforms upon which there had already developed a broad consensus, including parent participation.

122. E.g., Senator James Abourezk, Chairman of the Committee on Interior and Insular Affairs' Subcommittee on Indian Affairs, Congressman Lloyd Meeds, Chairman of the House Committee on Interior and Insular Affairs' Subcommittee on Indian Affairs, and Congressman Sidney Yates, Chairman of the House Appropriations Subcommittee on the Department of Interior and Insular Affairs. In a dramatic meeting held on August 16, 1974 in a large conference room in the Senate Office Building, BIA officials, Indians, and congressmen addressed the issue of why the BIA had not adopted the "Red Regs." Assembled were representatives from most of the thirty-eight organizations that had drafted the "Red Regs" as well as a large number of Indians from other organizations and tribes, some of the most influential members of Congress concerned with Indian Affairs, the Associate Solicitor for Indian Affairs of the Department of Interior, the Commissioner of Indian Affairs, and a group of BIA education officials. Spokespersons for the Indian groups included LaDonna Harris of Americans for Indian Opportunity, Kirke Kickingbird of the Institute for the Development of Indian Law, and Charles Wilkinson of the Native American Rights Fund. The show of unity had its desired effect.

123. 25 C.F.R. $\$ 33$ (1975). These regulations have been modified and renumbered because of the enactment of the Indian Self-Determination and Education Assistance Act which amends the Johnson-O'Malley Act as discussed in text accompanying notes 158-70 infra. With few exceptions, the substance of the 1974 Regulations is not significantly affected. See 40 Fed. Reg. 51303 (Nov. 4, 1975).

124. Sections 273.11, 273.12, 273.13, 40 Fed. Reg. 51303 (Nov. 4, 1975) contain no reference to tax-exempt land. 
schools; ${ }^{125}$ a system for equitable distribution of funds between and within states is established; ${ }^{126}$ the use of JOM for basic support is sharply circumscribed though not prohibited, ${ }^{127}$ parent participation provisions give Indian parents full veto power over proposed programs; ${ }^{128}$ and a system of fiscal accountability is established. ${ }^{129}$ Despite these major improvements, some issues still require further attention.

\section{E. Eligibility for Benefits}

The new regulations obscure rather than resolve the sensitive issue of whether urban Indians may participate in JOM programs. Program beneficiaries are defined as: "Indian students . . . recognized by the Secretary as being eligible for Bureau services." ${ }^{30}$ Although there may have been no intention to make substantial changes in the scope of JOM, the language chosen definitely includes many-though not all-urban Indians.

Despite many formal statements to the effect that the BIA has no responsibility for providing services to urban Indians, ${ }^{131}$ some services are in fact provided to Indians who reside in urban areas. Urban Indians, for example, are eligible to receive $\mathrm{BIA}$ scholarships to colleges, ${ }^{132}$ they may receive health services at Indian Health Services hospitals, ${ }^{133}$ and if they are beneficial owners of trust property they receive BIA property management services. ${ }^{134}$ These people, therefore, are indisputably "eligible for Bureau services."

While education programs are essential to meet the needs of urban Indians, the Bureau of Indian Affairs with its agencies located on the reservations is not particularly well equipped to administer those programs. With adequate funding, Part $A$ of the IEA can meet the needs of urban Indians. Since urban Indians in the past have been excluded from JOM, moreover, no widespread community expectations would be defeated by limiting the pro-

125. $\$ \S 273.12,273.37,40$ Fed. Reg. 51303 (Nov, 4, 1975). But see text accompanying notes $162-70$ infra.

126. $\S 273.13,40$ Fed. Reg. 51303 (Nov. 4, 1975). But see text accompanying notes 144-46 infra.

127. $\S 273.33-.34,40$ Fed. Reg. 51303 (Nov. 4, 1975).

128. Id. $\$ \$ 273.16-.17$.

129. Id. $\S \S 273.47,273.48,273.50$.

130. Id. §273.12.

131. E.g., Message From the President of the United States, H.R. Doc. No. 363, supra note 2, at 9. ("The Bureau of Indian Affairs is organized to serve the 462,000 reservation Inidans. The BIA's responsibility does not extend to Indians who have left the reservation, but this point is not always clearly understood.") Testimony of Morris Thompson, in FY 1976 House Appropriations Hearings 45 .

132. 25 C.F.R. \& 32.1 (1975) expressly authorized loans and grants to non-reservation Indians.

133. Although these facilities are located on the reservations, services are provided to any Indian who presents himself at an I.H.S. clinic or hospital regardless of where he lives. Sclar, supra note 108 , at 201 .

134. The services provided in connection with real property include maintenance of records, leasing, and probate. Trust funds are managed to increase their earnings. See id. at 199 and authorities cited therein. 
gram. Accordingly, Congress should act to confine the JOM program to reservation areas. ${ }^{135}$

\section{F. Basic Support}

The new regulations which sharply circumscribe the use of JOM monies for basic support appear to acknowledge, at long last, that such payments effectively subsidize discrimination by the states against Indian school districts. ${ }^{136}$ Districts now receiving JOM basic support payments will be phased out over a three year period. ${ }^{137}$ Under these circumstances, one would expect the regulations to contain no continuing authorization for basic support payments, but that is not the case. ${ }^{138}$ The cutting off of basic support funds to local districts will cause hardship until the states revise their programs of assistance to take up the slack. It remains to be seen whether the

135. An Act of Congress appears necessary to limit those eligible for JOM participation to certain geographic areas. See authorities cited in note 108 supra. Following the suggestion made by the Supreme Court of the United States in construing other legislation that the BIA may limit services based on "rationally made priorities," Morton v. Ruiz, 415 U.S. 199, 230 (1974), the BIA inserted a priority provision for contracts "which would serve Indian students on or near reservations." The BIA would be hard pressed to defend its present funding practices which award JOM monies to groups in urban areas such as Albuquerque, New Mexico and Rapid City, South Dakota but deny funds to groups in Seattle and Phoenix. The new regulations also embody an effort to define the term "reservation" to include non-reservation persons in Alaska and Oklahoma with the effect that off-reservation Indians in such places as Minnesota and Wisconsin are excluded. \& 273.2(0), 40 Fed. Reg. 51303 (Nov. 4, 1975).

136. To receive basic support funds, a school district must establish that:

(i) It cannot meet the applicable minimum State standards or requirements without such funds.

(ii) It has made a reasonable tax effort with a mill levy at least equal to the State average in support of educational programs.

(iii) It has fully utilized all other sources of financial aid, including all forms of State aid and Pub. L. 874 payments. The State aid contribution per pupil must be at least equal to the State average.

(iv) There is at least 70 percent eligible Indian enrollment within the school district.

(v) It shall clearly identify the educational needs of the students intended to benefit from the contract.

(vi) It has made a good faith effort in computing State and local contributions without regard to contract funds pursuant to this part.

(vii) It shall not budget or project a deficit by using contract funds pursuant to this Part.

$\S 273.13(\mathrm{~b})(1), 40$ Fed. Reg. 51303 (Nov. 4, 1975). In addition, upon receipt of an application for operational support, either the Area Director or the Commissioner must make a "federal written determination and findings supporting the need for such funds." $\$$ 273.24(e), 273.27(c), 40 Fed. Reg. 51303 (Nov. 4, 1975).

137. $§ 273.31(\mathrm{a}), 40$ Fed. Reg. 51303 (Nov. 4, 1975).

138. It appears that iribally operated schools may qualify for JOM basic support funds provided only that the funds are used to meet "established State educational standards or Statewide requirements." $\$ \$ 273.33,273.13$ (b)(2), 40 Fed. Reg. 51303 (Nov. 4, 1975). While BIA operational funding of tribal alternative schools is clearly desirable, it is not at all clear that these funds should be taken off the top of the JOM supplemental program. Further, this use of JOM for basic support was not discussed with Indian communities and organizations, and understandably the BIA's insertion of this provision has stimulated objections. See 40 Fed. Reg. 51286 (Nov. 4, 1975). 
$\mathrm{BIA}$ is capable of enforcing this significant change in the JOM program. ${ }^{139}$

\section{G. Equitable Apportionment of Funds}

In the past the BIA claimed that funds were distributed to the different states on the basis of need. ${ }^{140}$ In fact, the method of distribution was arbitrarily based in large measure on the previous year's allocation. ${ }^{141}$ Thus, in 1973, Nebraska was allocated $\$ 944$ for each eligible JOM pupil while South Dakota received $\$ 318$, Washington received $\$ 179$, and Idaho received $\$ 279 .{ }^{142}$ Similarly, within individual states the allocation between school districts varied widely. ${ }^{143}$

The 1974 regulations require apportionment of JOM supplemental funds among states based on the number of eligible students. This figure is then adjusted by taking into account the actual cost of delivering educational services in the state, which, like Part A of the IEA, is determined by reference to the state average per pupil expenditure. ${ }^{144}$ Although allocations based on the state average per pupil expenditures represent a vast improvement over past practices, the method of allocation can and should be further refined in order to ameliorate the disparities in educational resources among the states.

Within each state the JOM regulations require that funds be distributed among the contractors so that each will receive approximately the same amount for each eligible Indian student. ${ }^{145}$ Again, the regulations have opted

139. The BIA has "waived" some of the new requirements such as the 70 per cent Indian enrollment in a district so that otherwise ineligible districts may continue to receive JOM basic support funds. Public schools on the Navajo Reservation face severe financial problems. See Navajo Division of Education, Survival of the Public Schools (1975). However, this is due to Arizona's discriminatory finance scheme which yields unreasonably low levels of state aid to these schools. Arizona may threaten to close some of these reservation schools if the BIA does not exercise its discretion to release additional basic support funds. Similar problems exist in South Dakota.

140. See former 25 C.F.R. $\$ 33.4$ (b) (1975). It will be noted that the regulation refers to the need of the school district rather than the need of the Indian students.

141. E.g., Independent School Dist. No. 22 in New Mexico has regularly received a generous allocation of JOM funds despite the fact that in two recent years it generated a cash surplus of operating funds in excess of one million dollars. This information was developed in the course of preparing the case of Denetclarence v. Independent School Dist. No. 22, Civil No. 8872 (D.N.M., filed Feb. 14, 1974). See also testimony of Buck Benham, Assistant Area Director of Education, Bureau of Indian Affairs; Sam Mackey, Education Specialist, Bureau of Indian Affairs; and James McLarry, Acting Director of Indian Education, New Mexico State Dep't of Education, in Hearings on H.R. 8937 E S. 2482, supra note 39, at 120-21.

142. These figures are derived from U.S. Dep't of Interior, Fiscal Year 1973 Statistics Concerning Indian Education 39, Table 16 (1974) and BIA data showing Johnson-O'Malley funding by states in Hearings on Dep't of the Interior and Related Agencies Appropriations Fiscal Year 1975, supra note 12, at 1324-25.

143. E.g., An Even Chance 13.

144. $\$ 273.31,40 \mathrm{Fed}$. Reg. 51303 (Nov. 4, 1975). The regulation requires only that allowance be made for the actual cost of delivering services in each state, but in practice the BIA has used state average per pupil expenditures to make the adjustments.

145. $\S 273.31$ (b), 273.31(3), 40 Fed. Reg. 51303 (Nov. 4, 1975). 
for equity and stability. One consequence is that the funds will not necessarily be allocated to those most in need, but since there is no satisfactory way to make a meaningful determination of educational need and since the commissioner retains discretion to make exceptions to per capita allocations where a community can demonstrate special needs, the regulation appears as satisfactory as can be expected. In addition, several of the programs administered by the Office of Education are discretionary, and relative need is presumably considered in these allocations. ${ }^{146}$

\section{H. JOM Today}

In hearings considering the 1975 appropriations request for JOM, Senator Alan Bible, Chairman of the Senate Appropriations Subcommittee, made the following statement: "Johnson-O'Malley has been a bugaboo for years around here. I do not know if anybody has been particularly satisfied. We get a lot of complaints on it." ${ }^{147}$ Clearly Senator Bible's dissatisfaction with the JOM program was well founded. Many of the past problems have been sufficiently eliminated or ameliorated by the new regulations (which had not been promulgated when Senator Bible spoke) to warrant continuation of the program.

The strongest argument for the abolition of JOM is the possibility of duplication with IEA, Part A, which-like JOM-provides monies on a per capita basis for educational programs to meet the special educational needs of Indian children. While there is an undeniable overlap in permissible expenditures under the two programs, the relevant inquiry would seem to be whether or not the overlap results in the duplication of benefits to Indian children. Given the present low level of appropriations, the likelihood of duplication of benefits appears remote. In fiscal year 1975, for example, Congress appropriated only $\$ 23$ million for Part A which resulted in an average distribution of only $\$ 85$ per pupil, ${ }^{148}$ and JOM yielded an average of $\$ 203$ per pupil. ${ }^{149}$ In most of the reservation school districts which now operate both programs, the level of basic support is far below the national average ${ }^{150}$ so that there is a broad area to be covered by compensatory programs.

In the future, however, Part A funding should be substantially increased

146. In addition to IEA, Part B, the U.S. Office of Education administers discretionary programs for bilingual education, 20 U.S.C. $\$ 880$ (b) (1970); dropout prevention (ESEA Title VIII); and school libraries (ESEA Title II).

147. Hearings on Dep't of the Interior and Related Agencies Appropriations Fiscal Year 1975, supra note 12 , at 1319 .

148. FY 1976 House Appropriations Hearings 287. This sum does not include a ten per cent set aside for Indian controlled schools located on or near reservations which are not local educational agencies. 20 U.S.C. $\$ 24 \mathrm{lbb}(\mathrm{b})$ (Supp. III, 1974).

149. This figure was derived by dividing the 1975 appropriation of $\$ 28,352,000$ by 105,000 eligible Indian students. FY 1976 House Appropriations Hearings 26-27, 56. In 1975, 25 per cent of the JOM appropriation went for basic support.

150. See, e.g., testimony of Herbert Jacobson, Planning Officer, Office for Indian Education, in FY 1976 House Appropriations Hearings 307-08. 
in order to insure that off-reservation children will receive a fair share of relevant educational services. As Part A funding begins to approach its full authorization of approximately $\$ 387$ million, ${ }^{151}$ Congress could appropriately decrease its support of JOM. At present, however, the availability of monies from both JOM and Part A makes it possible for reservation Indian communities to establish priorities such as early childhood projects, curriculum development, and remedial reading and to allocate the available funds in an orderly manner.

Given the substantial improvements made by the 1974 regulations, there are several compelling reasons why the JOM supplemental program should be continued for reservation Indian children. First and foremost, Indian communities have in recent years been more actively involved in JOM than with any other education program. JOM parent committees exist on almost every federal reservation in the nation, and Indian parents have invested incalculable time and energy in attempting to devise sound programs for their communities. Should Congress terminate the JOM program, many Indian people would feel a deep sense of betrayal to their hopes and aspirations. Indeed, the active involvement of Indian parents in the education of their children contributes to the greater potential success of the entire program. The assistance given to facilitate their involvement should, therefore, be continued.

Secondly, the JOM program is far more flexible than any of the other federal education assistance programs-a situation uniquely desirable for the varied circumstances facing Indian reservation communities and educational institutions. JOM funds may be used in school or in the community, for parental costs related to education, for travel, or for summer programs. Moreover, JOM contractors may be an Indian corporation, a school district, or a state. In contrast, recipients of grants under Title I and IEA, Part A, must be local educational agencies (i.e. public school districts) and as a result the educational programs funded by those acts are likely to be tied to a traditional "school." Yet the geographical dispersion of rural reservation Indian children may make it more desirable to hold an educational program at some other location.

Thirdly, reservation school districts, taken as a whole, have fewer resources of all types-financial, cultural, educational-than do non-reservation school districts taken as a whole. Most reservation students live in comparatively isolated communities. The cost of a trip to the state capital or to a large art museum is likely to be greater for a reservation student than for an urban student. In short, the spectrum of needs which can be addressed by compensatory education are demonstrably greater for most reservation students than for most urban students. The perpetuation of the JOM program provides a useful vehicle to accommodate these needs.

151. FY 1976 House Appropriations Hearings 287. 


\section{Duplication of Administration}

Where both JOM and the IEA, Part A programs operate in school districts, there is presently some duplication of administrative expenses which can be avoided. For example, both programs require committees of Indian parents to review, develop, and approve proposed projects. These parent committees can be combined, as was apparent to Congress when, in section 202 of the Indian Education Assistance Act, it provided, "in the discretion of the affected tribal governing body or bodies," 152 for the utilization of one board for both purposes. In view of the differing requirements for composition of the parent committees under the two programs ${ }^{153}$ and the possibility of different views concerning the best means to meet the educational needs of Indian students, it is conceivable that in some instances the two committees should not be combined. The tribal governing body is usually sufficiently informed to make the appropriate determination. ${ }^{154}$

Where the JOM contract administrator is an Indian corporation, expenses of administration will be incurred which might be saved if all contracts were required to be run through the state and public school district. As a policy matter, however, Congress has decided to encourage Indian administration of Indian programs even if it will result in some additional administrative expense. The experience gained by the Indian corporation in program management may itself be viewed as educational and the fact of Indian control may promote increased Indian participation in the funded programs. Finally, it will be noted that the JOM program administered by the BIA prevents the centralization of all federal education programs in the United States Office of Education. In the past, this separation has resulted in lack of coordination between the two agenices. ${ }^{155}$ Part of the duplication can be reduced by coor-

152. Pub. L. No. 93-638, § 202(5)(b), 88 Stat. 2212 (Jan. 4, 1975).

153. Compare 20 U.S.C. $\$ 24 \mathrm{Idd}(\mathrm{b})(2)(B)$ (Supp. III, 1974) and 45 C.F.R. $\$ 186.15-16$ (1975) with Pub. L. No. 93-638, § 202, 88 Stat. 2212 (Jan. 4, 1975) and 25 C.F.R. $\$ 33.3$ (1975), now $\S 273.16,40$ Fed. Reg. 51303 (Nov. 4, 1975). The IEA parent committee may include teachers, students, and at least 50 per cent Indian parents who are selected by procedures arranaged by the local school district, while the JOM committee consists of persons elected by Indian parents.

154. The importance of the parent participation and control provisions to Indian communities and the difficulty of legislating workable guidelines on a nationwide basis should not be underestimated. In many communities control of the JOM and Title IV budget may amount to considerable political and economic power. In some instances this power may be used to force local school districts to become more responsive to the Indian community, and in others it may be used to challenge the authority of the tribal council or to advance other interests. The Parent Advisory Councils of the 1970 s should be viewed as having almost the same capacity for changing the status quo on Indian reservations as the OEO programs of the late $1960 \mathrm{~s}$.

The present JOM and Title IV regulations providing for separate committees but authorizing consolidation of the two in the discretion of the tribal council appear flexible enough to accommodate the diverse conditions found in Indian communities throughout the nation. A legislative requirement that there be only one PAC within a school or school district might appear more efficient, but may impose an unintended and undesirable alteration in the balance of power within Indian communities.

155. Cf. FY 1976 House Appropriations Hearings 310. 
dination of the parent committees at the local level, and, as an ever increasing percentage of JOM monies are contracted directly with Indian corporations ${ }^{156}$ and expended outside the public school system, the need for coordination at the federal level is reduced. ${ }^{157}$

\section{J. New Amendments}

The Indian Self-Determination and Education Assistance Act added three new sections to the Johnson-O'Malley Act. ${ }^{158}$ Section four requires that prospective JOM contractors submit for advance approval a "plan of educational objectives." 159 Section five makes parent committees from the local community a statutory requirement ${ }^{160}$ and section six authorizes the Secretary of Interior to reimburse local school districts for the cost of educating Indian children

156. At present tribal groups administer the entire JOM program in Wisconsin, South Dakota, North Dakota, Florida, Alaska, Utah, Nebraska, and in approximately half of New Mexico. BIA data in FY 1976 House Appropriations Hearings 63. This represents more than one third of the entire JOM appropriations.

157. A major breakthrough in inter-agency coordination could be achieved simply by redesigning the Title $\mathrm{IV}$ and JOM application forms so that they would indicate the programs and projects for which funding has been received or is being sought in the district.

158. 25 U.S.C. $\S 455$ (1975).

159.

The Secretary of the Interior shall not enter into any contract for the education of Indians unless the prospective contractor has submitted to, and has had approved by the Secretary of the Interior, an education plan, which plan, in the determination of the Secretary, contains educational objectives which adequately address the educational needs of the Indian students who are to be beneficiaries of the contract and assures that Id. the contract is capable of meeting such objectives.

160 .

(a) Whenever a school district affected by a contract or contracts for the education of Indians pursuant to the Act has a local school board not composed of a majority of Indians, the parents of the Indian children enrolled in the school or schools affected by such contract or contracts shall elect a local committee from among their number.

Id. $\$ 456$. The section goes on to provide that the Secretary shall prescribe by regulation the duties and structure of the local committees. See $\S 273.16,40$ Fed. Reg. 51303 (Nov. 4, 1975). Section 456 also contains the provision authorizing the use of the Title IV board in place of a new JOM committee in the discretion of the tribal council. See text accompanying notes 152-54 supra.

The statutory language quoted above exempts school boards composed of a majority of Indians from the parent committee provisions. Since most school board members-both white and Indian-tend to be employed full time in endeavors other than education, it would seem that the views of Indian parents should be just as helpful to Indian school board members as to nonIndian school board members. An Indian controlled school board failed to detect and correct a pervasive pattern of racial discrimination in the Gallup-McKinley school district. See Natonabah v. Board of Educ., 355 F. Supp. at 716. And an Indian controlled school board in the Shiprock. New Mexico district failed to require the district to provide a bilingual education program adequate for the needs of Indian children in the district. See Denetclarence v. Independent Dist. No. 22, Civil No. 8872 (D.N.M., filed Feb. 14, 1974). This provision appears to be based on the dubious assumption that Indian school board members have substantially more time to delve into the day to day operations of a school district than do non-Indian school board members. In many instances, moreover, the background of a person-Indian or non-Indian-who has the time and money to run for public office may differ significantly from that of the parents of edu- 
from other states who reside in federal dormitories. ${ }^{161}$ One portion of the Act, however, appears to be a serious congressional error. Section four contains the following proviso: "Provided, that where students other than Indian students participate in such programs, money expended under such contract shall be prorated to cover the participation of only the Indian students." ${ }^{162}$ This provision addresses two troubling and persistent problems which arise in connection with JOM. In predominantly Indian schools or classes it seems unfair to exclude on the grounds of race a handful of non-Indian children from JOM funded programs such as an excursion to the state capitol or remedial reading. ${ }^{163}$ Secondly, many school districts are unable to support programs such as kindergarten that are desirable for all students without the use of JOM monies. Since JOM monies are appropriated "for Indians," at first glance it appears reasonable to permit non-Indian participation in JOM funded activities on the condition that unrestricted funds be used to support the non-Indian portion of the program.

On closer examination, however, it seems clear that to the extent the provision is utilized, it converts a supplemental program into basic support, thereby vitiating one of the most significant recent reforms in the JOM program. If, for example, a school district offers a kindergarten program for all children and prorates the cost between JOM and state and local monies in proportion to the ratio of Indian to non-Indian children, the JOM funds supplant the other monies. ${ }^{164}$ In the case of Denetclarence v. Board of Education

cationally deprived children, and it is this latter group that needs a greater voice in education decisions.

161. In New Mexico, Arizona, South Dakota, and Alaska the Bureau of Indian Affairs operates dormitories for Indian students living in remote areas not readily accessible to public schools. Through the so-called "bordertown" domitory program, Indian students attend public school in districts reasonably close to their home communities. In the past, the BIA paid full tuition to the public school district for each Indian child, but in 1970 the Comptroller General issued a report criticizing the BIA for this practice. The Comptroller General's Report noted that the education of Indians is the responsibility of the states, that in addition to BIA tuition payments, the local school districts also collected P.L. 874 payments and state A.D.A. payments for each Indian child which resulted in a financial windfall to the local school districts. This section authorizes the Secretary of Interior to make full tuition payments to local school districts only when the Indian children attending school reside in a state other than the one in which the school is located.

Payments under this section should be scruntinized carefully. It is possible, for example, that Indian children will be shipped from North to South Dakota or from Arizona to New Mexico not because schools are unavailable in their home state, but because extra federal monies can be generated by crossing state lines. Indeed, the bordertown dormitory program is something of an anachronism. As more roads are built every year on the reservations, the number of children living away from home in federal dormitories should decline steadily.

162. Pub. L. No. 93-638, tit. II, § 202, 88 Stat. 2213 (Jan. 4, 1975).

163. An analysis of the relationship between Indian law and civil rights law is contained in Rosenfelt, supra note 5, at 530-50. Briefly, that article suggests that the seemingly conflicting constitutional policies against racial classifications but in favor of Indian tribal sovereignty can be reconciled.

164. The term "supplanting" refers to the use of federal categorical aid to replace state and local support for an educational program available to all students. See, e.g., 45 C.F.R. \& 116.17(h) (1975). 
of Independent School District No. 22, the Secretary of Interior and the Secretary of Health, Education and Welfare voluntarily bound themselves to a federal court judgment which specifically identified this practice as constituting a misuse of JOM funds. ${ }^{165}$ While Congress has the power to make this major change in the law, there is no indication-apart from the statutory language-that it intended to do so. The provision did not appear in the drafts of the bill which were circulated to Indian people, and it is not mentioned in the committee reports. ${ }^{166}$

Even more serious, the proration provision, in effect, purports to authorize racial discrimination against Indian children-a result which Congress obviously did not intend. ${ }^{167}$ Where state or local funds are used to provide educational services for non-Indians, the services must also be provided for Indian children on the same terms and conditions and to the same extent. ${ }^{168}$ This goes to the very essence of equal educational opportunity. Providing identical educational services from separate funding sources may appear unobjectionable, but it is not far removed from the provision of identical services in separate facilities and, ultimately; the provision of unequal services. Where such distinctions are based solely on race, the Constitution is offended.

If Congress wishes to authorize non-Indian participation in JOM programs where such participation would not dilute the effectiveness of the project, it should do so directly. ${ }^{169}$ In order to protect the integrity of the project,

165. Civil No. 8872 (D.N.M., filed Feb. 14, 1974) incorporating Agreement of Parties dated Dec. 14, 1973. Paragraph 14 of the Agreement of Parties includes the following:

All children located in district schools not on the reservation were eligible to attend kindergarten at Ruth N. Bond Elementary School in Kirtland. The kindergarten program at the Bond school was funded partially by operational funds and partially by Johnson-O'Malley funds on a prorata basis. The Johnson-O'Malley contribution to the kindergarten at Bond Elementary School was approximately equal to the percentage of Navajo students who attended the kindergarten there. The provision of such services from Title I and Johnson-O'Malley funds constituted supplanting of state and local funds by federal categorical aid.

166. H.R. ReP. No. 1600, 93d Cong., 2d Sess. (1974); S. Rep. No. 762, 93d Cong., 2d Sess. (1974).

167. Section 205 of the same Indian Education Assistance Act expressly requires school districts receiving JOM funds to provide "the quality and standard of education . . for Indian students ... at least equal to that provided all other students from resources . . available to the local school district." Pub. L. No. 93-638, tit. II, \$ 205, 88 Stat. 2213 (Jan. 4, 1975). It appears impossible to reconcile the proration provision with this stricture.

168. Natonabah v. Board of Educ., 355 F. Supp. 716 ; Hobson v. Hansen, 269 F. Supp. 401 (D.D.C. 1967), aff'd en banc sub nom. Smuck v. Hobson, 408 F.2d 175 (D.C. Cir. 1969); Hobson v. Hansen, 327 F. Supp. 844 (D.D.C. 1971); $c f$. Brown v. Board of Educ., 347 U.S. 483, 493 (1954). See also 42 U.S.C. $\S 2000$ d (1970); 43 C.F.R. $\S \S 17.1,17.2,17.3$ (b); United States v. Jefferson County Bd. of Educ., 372 F.2d 836, 899-900 (5th Cir. 1966), aff'd per curiam on rehearing en banc, 380 F.2d 385 (5th Cir.), cert. denied, 389 U.S. 840 (1967).

169. Title I regulation 45 C.F.R. $\$ 116.17$ (a) (1975) permits the participation of educationally deprived children who live outside the project area "if such a participation will not dilute the effectiveness of the project with respect to children residing in the project area." The analogy to JOM is not a true one, however, because in the Title I example all participants will be "educationally deprived children" who are within the class of beneficiaries designed by Congress. For 
however, any non-Indian participation should be expressly approved by the local Indian parent committee and a minimum ratio of Indians to nonIndians should be prescribed. ${ }^{170}$ In all events, the proration proviso should be repealed.

\section{Conclusion}

During the last half decade the Indian Education Act, the Indian SelfDetermination and Education Assistance Act, the revised Johnson-O'Malley regulations, and the improved administration of Title I have created a statutory and administrative framework which makes it possible for Indian communities to shape educational programs in a more flexible, relevant, and responsive manner. Equally important, the nationwide recognition of the inequities resulting from a school finance system based largely on local real property taxation and the movement for increased state funding and equalization of local school budgets provide further assistance for the education of Indian children. In order to achieve greater equity in the allocation of resources and to improve the efficiency and responsiveness of educational agencies at all levels of government, further legislative refinements, such as those suggested here, are needed. In general, federal financial assistance to the states must be coupled with federal insistence that the states discharge their responsibility to provide an adequate basic education program in a nondiscriminatory manner. The major federally funded compensatory education programs serving Indians are basically sound. With the development of rational funding priorities and the adoption of specific, minor amendments, the efficacy, efficiency, and equity of the compensatory programs will be immeasurably enhanced.

JOM, however, the class of beneficiaries is limited to "Indians." 25 U.S.C. $\$ 452$ (1970). It should be noted that neither the Indian Education Act nor its regulations addresses this issue. If Congress considers the question of non-Indian participation in JOM, it should do the same with the IEA.

170. It must be noted that large numbers of Indian people feel strongly that JOM benefits should be limited exclusively to Indians and that activities suitable for all students should be funded by operational monies. If Congress were to authorize the expenditure of JOM monies for non-Indians even under the restrictive provisions suggested above, Indian parent committees might perceive pressure from school administrators and their non-Indian neighbors which would induce them to give a high priority to the preservation of racial harmony in place of the educational needs of their children. In this instance, then, the consequences of a broad delegation of authority to local Indian parent committees should be considered most carefully. 
